\title{
Elite Collusion and African Governance System: A Critique of Democracy and Development in Nigeria
}

\author{
Abdulhamid Ozohu-Suleiman ${ }^{1} \&$ Shehu Mustapha Liberty ${ }^{2}$ \\ ${ }^{1}$ Department of Public Administration, Faculty of Management Sciences, University of Abuja, Nigeria \\ ${ }^{2}$ Department of Public Administration, Faculty of Management Sciences, University of Maiduguri, Nigeria \\ Correspondence: Abdulhamid Ozohu-Suleiman, Department of Public Administration, Faculty of Management \\ Sciences, University of Abuja, Nigeria. E-mail: aburahmama@gmail.com
}

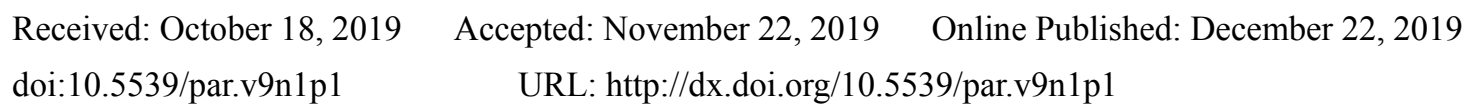

\begin{abstract}
Following the commencement of the third wave democratization in Africa, scholarly preoccupation shifted, or at least began to shift away from the over flogged discourse on colonial antecedents and authoritarian rule among others, as explanations for governance failure in the continent. Thus, the prevailing liberal political conditions now offer a new perspective to articulate the development problematic in emergent democracies of Africa. This paper seeks to examine how the negative outcomes generated by this governance system have made development the casualty of the democratization process in Nigeria. It advances the thesis of elite collusion to provide insights into the causes of governance failure in Nigeria. The paper argues that the hegemonic interest of the ruling elite remains the predominant factor that narrowly defines public policy. By means of interpretative approach the paper reviewed secondary data from extant literature and development reports that are Germaine to the subject matter of the study. It established that much of the development deficit is the predictable consequence of the disconnect between the common good and state policy/institutional action. This disconnect is exacerbated by a political environment that is overwhelmed by self-seeking and unpatriotic ruling elite. The paper concludes that; democracy, though, a necessary condition for good governance and sustainable development, requires an ideologically driven party politics to reconstruct the prevalent governance system. A number of recommendations are made among which are; an urgent need to build strong governance institutions that are rule bound (re-bureaucratization) in order to neutralize elite collusion, and a realignment of the democratization process to embrace the variant of social democracy - an option that prioritizes the participation of the masses in the development process.
\end{abstract}

Keywords: democracy, democratization, development, elite, governance, masses, political conditions

\section{Introduction}

Contemporary Africa is a product of three significant historical epochs, namely; the colonial epoch, the epoch of self-rule (after the winning of political independence), and the epoch of democratization (following the onset of the third wave transitions to democracy). Thus, beginning with the status of an obscure continent that offered opportunities for political subservience and economic plunder (under colonialism), through a chequered history of political developments (under self-rule), to the onslaught of third wave democratization of the 1990s), contemporary Africa has continued to be an engaging subject of intellectual reflections. Much of these reflections have swelled up the literature on the diagnosis and prognosis of colonialism. Beyond colonialism, the discourse on post-colonial Africa has sought to situate the continent within a broader framework of international political economy. Thus, there is a consensus (especially among indigenous scholars that much of Africa's development problematic is not unconnected to the global system of unequal exchange.

However, the intellectual preoccupation with the political hegemony of the imperial powers of Europe and America as the underlying cause of Africa underdevelopment is now debatable following a fairly long period of political independence, the meteoric rise of the 'Asian Tigers' from the ashes of colonialism and the onset of the third wave democratization in the continent. In the context of these developments, scholars are beginning to articulate new perspectives on the political and socio-economic conditions of the continent. Thus, factors such as internal political crises characterized by authoritarian rule, the phenomenon of sit-tight leadership, corruption and lack of accountability became plausible explanations for the development problematic in Africa. The call for 
regime transformation from authoritarian rule to liberal democracy became widespread following the deteriorating socio-economic condition of the vast majority of the people of the continent. This call provided the impetus for the third wave which made its course into the continent of Africa in the 1990s.

Regime transformation and the subsequent democratization process meant for the African continent a watershed in her chequered political development. The significance of this development lies in the opportunity it accords the people of the continent to choose their leaders through a predictable electoral process, and the liberal political environment it engenders to enable people participate in the governance process that shapes their lives. In other words, the good news about the development is that, democratization was meant to provide the institutional and procedural guarantee that policies and laws made by government (the state) will fit reasonably with the common good of the people - in the direction of improving the existential conditions of life and the ability of the people to enjoy their constitutionally guaranteed freedom. It is over three decades since the third wave of democracy tarried in Africa and the liberal political conditions and institutional infrastructure it engendered have provided new and refreshing perspective to the general discourse on the socio-political and economic development of the continent.

A preponderance of African states including Nigeria are in the frontline status of democratizing societies. However, many of these democratizing societies are equally marred by one form of socio-political crisis or the other. This development has thrown up debates on the possibility of reversal. Huntington's (1991:17) submission on the factors that are capable of precipitating a reversal is corroborated by the crisis of development in many African states. Two of these factors are instructive here: "the weakness of democratic values among key elite groups and the general public; and severe economic setbacks which intensified social conflict and enhanced the popularity of remedies that could be imposed only by authoritarian government".

For African states (like Nigeria) that have recorded nineteen years of unbroken democratization process, the question is; how has the liberal political conditions and institutional infrastructure of democracy impacted on her governance situation? What explanations can possibly be advanced to justify the deteriorating existential conditions of the vast majority of the people? This paper advances the thesis of elite collusion to provide insights into the cause of governance failure in Africa's most populous democracy. It argues that democracy is not so much a governance system that guarantees performance legitimacy but more of a framework of organizing societies such that collective decisions are the indirect expression of the citizens through their representatives. What remains to be determined is how these decisions have helped to facilitate the realization of the collective hopes and aspirations of the governed. The paper further submits that, elite collusion is itself a governance system nurtured and sustained by liberal political conditions. Thus, the hegemonic interest of the ruling elite remains the predominant factor that narrowly defines public policy in Nigeria. In the light of this thesis, the paper interrogates the democratization process in regard to government commitment to liberalize the political space, institutionalize good governance and promote development.

\section{Third Wave Democratization and the Development Problematic}

Almost three decades of the third wave democratization has witnessed the emergence of a considerable number of democracies in Africa, with varying degrees of progress. The allusion to the word 'progress,' has two different but interrelated connotations. On the one hand, it is used to describe the incremental change that has been recorded in democratizing the processes and institutions of governance, the most instructive of which is the efforts to institutionalize a predictable electoral process that takes care of leadership succession. On the other hand, progress is also used to describe development that leads to significant and continuing improvement in the quality of life for the vast majority of the people. In other words, progress report on democratization in Africa has two sides of a coin. On the one side is democracy and on the other side is development. The question as to whether these two sides are mutually reinforcing in Africa is debatable, and extant literature is replete with reports about the experiences of democratizing states of Africa.

Scholars have been unsparing in their treatment of the irresistible advances of democracy on a World scale (Huntington, 1991; Michael and Van de Walle, 1992; Ake, 2000; Adejumobi, 2004; Lynch and Crawford, 2011; Sesay,2014; and Ibori and Anakwe, 2017). In the opinion of Huntington, the major factor that has contributed significantly to the occurrence and timing of the third wave transition to democracy is:

The deepening of legitimacy problem of authoritarian regimes in a world where democratic values were widely accepted, the consequent dependence of these regimes on successful performance, and their inability to maintain "performance legitimacy" due to economic (and sometimes military) failure (Huntington, 1991:13). 
Thus, the impetus for the onset of democratization in Africa lies in the pathology of authoritarian/sit tight rule (which stifle personal and collective liberty and encourage social exclusion), contributing to the poor quality of public administration (where the institutions of public service lack the capacity to deliver on existential requirements of the people). In addition to the foregoing, is what is generally considered in the literature as exogenous pressure from western nations, donor agencies and international financial institutions (who have continued to demand democratic reforms as pre-condition for development assistance (Anifowoshe and Enemuo cited in Ibori, 2017). However, the continent of Africa still parades a handful of sit-tight dictators, many of who bestride the narrow world of their countries like colossus. Table 1 below clarifies the statistics.

Table 1. Sit-tight leaders in Africa

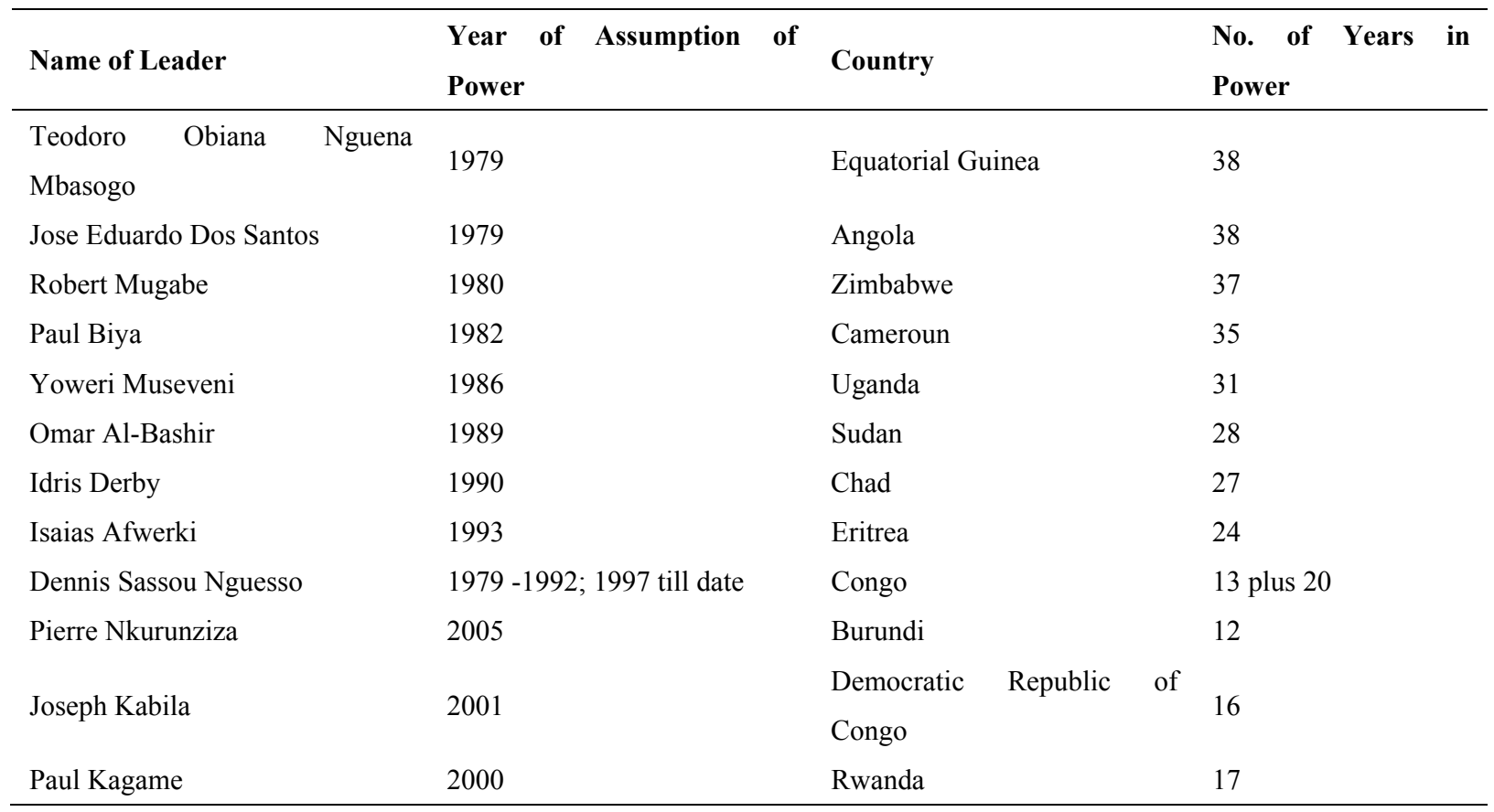

Source: Daily Trust Newspaper, Nigeria, May 15, 2016

Also worth acknowledging is the role of the African Union (AU) in Africa transition to democracy through its African Governance Architecture (AGA). An important component of AGA is the African Charter on Democracy, Elections and Governance, with responsibility to "entrench in the continent a political culture of change of power based on the holding of free, fair and transparent elections conducted by competent, independent and impartial electoral bodies" ( Sesay, 2014: ). Therefore, the relative progress that has been recorded on multiparty election in Africa, since the 1990s, is due largely to the commitment of the AU to; Promote the universal value and principles of democracy, good governance, human rights and the right to development (Sesay, 2014).

However, whereas we can conveniently claim (based on available evidence) that a preponderance of African states has transited to democracy, the same claim cannot be made of the development of the continent (especially in states where the third wave has tarried for a while). The question then arises: how much has democracy delivered on its mandate of development? Scholarly efforts to address this question have led to a profound intellectual polemics on the democracy -development nexus, with many African scholars being circumspect about their treatment of democracy as the precursor of development (Johnson, 1991; Ake, 2001; Adejumobi, 2004; UNDP, 2006 and Ozohu-Suleiman, 2016).

We recall that the narrative of deprivation was predominant in the mass movement of the 1990s (especially in Nigeria), on this note, Nzongola-Ntalaja (2004), averred that democratization was expected to provide a system that maximizes the responsiveness of the rulers to the expressed interest and needs of the public. Responsiveness translates to good governance which implies the efficient management of state institutions and resources in accordance with the rule of law to promote the general welfare of the citizens. Good governance embraces such requirements as efficiency, curbing corruption which inhibits development and investment, guarantee of civil and 
human rights and accountability to the people (Johnson, 1991). It also includes an appropriate political leadership and environment that furnish a predictable and transparent framework of rules, institutions and behavior for the management of public affairs (Adejumobi, 2004).

The contention of the democracy-development is not about whether democracy can engender development; rather, it is about how best democracy should execute the development agenda on a sustainable basis. Therefore, democracy should seek in common with good governance, efficient public administration and predictable economic and political environment that make economic growth possible and development sustainable (UNDP, 2006). However, the persistent failure of development in Africa have led some scholars to argue that, good governance and development are not about a mode of polity or a procedural arrangement, but a holistic and consequential variable. In this context, what matters is not necessarily the form of government, but the result of governance. It is about effective and productive governance (Dun, 1986 and Adejumobi, 2004). For most states in Africa that have transited to democracy, the objective reality is that democratization is yet to bring about the much needed development to the vast majority of the people. This observation led Adejumobi to conclude that:

Liberal democracy is essentially a class project that reflects dominant power interests... its crafting and hegemonic interest that it represents is largely that of capital and bourgeois class. That is why issues of private property and accumulation are emphasized and well protected in the constitutional order of western democracies, while that of equality and socio-economic rights are more abstract than real for the majority of the people (Adejumobi, 2004:13).

Even the notion of equality and/or representation which democracy espouses is severely scored (at least in the context of African experience). Thus, Yaqub argues that:

...Construed exclusively in term of abstract personhood or legal and electoral equity, (equality) omits the crucial economic and social determinants that shape its real life connotation. In the absence of community, equality is a fiction that not merely divides, as easily as it unites but that raises the specter of a mass society made up of indistinguishable consumer clones (Yaqub, 1994:158).

On this note, the "performance legitimacy" (Huntington, 1991) of African democracies is severely scored. In his The End of Democracy, (Abid Ulla-Jan, 2003:54), reported two fundamental problems (among others) that compromise the performance legitimacy of democracy. They are; the continual attempt by special interest to steal the wealth of the commons, and a growing disparity between the rich and the poor Thus, more than three decades after the onset of democratization, the continent of Africa is immersed in poverty, economic stagnation, misery, violence and socio-political instability. These negative social realities are the predictable consequences of the absence of inclusive development. Although democratic reforms have engendered favourable policy environment for modest macro-economic performance, the resulting economic expansion has not contributed meaningfully to the material well-being of the citizens. This scenario has been described by Lewis (2008: 67) as the paradox of "Growth without Prosperity". He observed that there may be evidence that; "political liberation bolsters economic policy reform and enhances some institutional requisites of economic performance. Yet there are few signs that these improvements foster significant reduction in poverty and inequality (Lewis, 2008:69). Table 2 below provides data on trends in macro-economic development in African between 2014 and projecting into 2019. 
Table 2. Macroeconomic developments in Africa, 2013 - 2019

\begin{tabular}{|c|c|c|c|c|c|c|c|}
\hline Variable & $2009-19$ & 2014 & 2015 & 2016 & 2017 (Estimate) & 2018 (Projected) & 2019 (Projected) \\
\hline \multicolumn{8}{|c|}{ Real GDP Growth (Percent) } \\
\hline Central Africa & 4.3 & 5.7 & 3.1 & 0.1 & 0.7 & 2.4 & 3.0 \\
\hline East Africa & 5.3 & 5.9 & 6.5 & 4.9 & 5.6 & 5.9 & 6.1 \\
\hline North Africa & 4.1 & 1.9 & 3.7 & 3.3 & 5.0 & 5.1 & 4.5 \\
\hline Southern Africa & 3.1 & 2.7 & 1.6 & 0.9 & 1.6 & 2.0 & 2.4 \\
\hline West Africa & 6.5 & 6.0 & 3.2 & 0.5 & 2.5 & 3.6 & 3.8 \\
\hline Africa & 4.6 & 3.8 & 3.5 & 2.2 & 3.6 & 4.1 & 4.1 \\
\hline
\end{tabular}

Source: African Development Bank (AFDs) Statistics Department, 2018.

The above trends indicate that after over three decades of the onset of democratization in Africa, real Gross Domestic Product (GDP) only recorded modest growth of 3.8 in 2014 and 3.5 2015, plummeting to 2.2 in 2016. This deep slide in GDP (at a time that the democratization process was expected to provide the enabling environment for consolidating macro-economic performance), remains a sad commentary on the quality of political leadership in the continent. Beyond the obvious evidence of macroeconomic indicators, data on poverty and human development do not reflect significant improvement in the existential conditions of the people. The Human Development index (HDI) provides further insights into the quality of life, (measured in terms of average income, life expectancy, education and literacy). Table 3 below illustrates the trends in selected African states between 1985 and 2004.

Table 3. Human development index (HDI) in selected African democracies, 1985 - 2004

\begin{tabular}{llllll}
\hline & $\mathbf{1 9 8 5}$ & $\mathbf{1 9 9 0}$ & $\mathbf{1 9 9 5}$ & $\mathbf{2 0 0 4}$ & Difference (1990/2004) \\
\hline SSA & 0.45 & 0.46 & 0.46 & 0.47 & +.02 \\
Benin & 0.37 & 0.37 & 0.40 & 0.43 & +.06 \\
Botswana & 0.64 & 0.68 & 0.66 & 0.57 & -.07 \\
Ghana & 0.48 & 0.51 & 0.53 & 0.53 & +.05 \\
Madagascar & 0.44 & 0.45 & 0.46 & 0.51 & +.07 \\
Mali & 0.26 & 0.29 & 0.31 & 0.34 & +.08 \\
Mauritius & 0.69 & 0.73 & 0.75 & 0.79 & +.10 \\
South Africa & 0.70 & 0.74 & 0.74 & 0.65 & -.05 \\
Zambia & 0.49 & 0.46 & 0.43 & 0.41 & -.08 \\
\hline Net across countries & $1990-2004$ & & & & +.16 \\
\hline Average & & & & & +.02 \\
\hline
\end{tabular}

Source: UNDP, accessed at http://hdr.undp.org/hdr2006/statistics/flash/statistics_trends.cfm

The above trends indicate that in 1985 when most states in Sub-Saharan Africa (SSA) were under authoritarian rule, the HDI value was 0.45 , increasing marginally to 0.46 in 1995 . By 2004 when the democratization process was well over one decade, the HDI value in SSA democracies was merely 0.47 . This emerging empirical evidence has provided new and refreshing insights into the democracy-development nexus. Part of these insights focus on the governing elite, and how their performance based legitimacy, (which should take precedence over mere procedural legitimacy) has impacted on the development process (Leftwich, 2000).

\section{Elite Collusion as Governance System}

Contemporary articulations of the concept of governance system have included a relentless effort by scholars to respond to the increasing perversion of democracy as a governance system. Such conceptual vernacular as: 'pseudo democracy' (Case, 2004); 'Hybrid Regime' (Brownlee, 2009); and 'Feckless Democracy' (Diamond, 
2014), have been employed to explain the failure of liberal democracy enterprise in Africa. This section of the paper is devoted to similar intellectual preoccupation by constructing a variant of governance system that seeks to expose the fault lines of the democratization process in Africa. This variant is referred to as 'elite collusion'. We proceed by first clarifying the concept of governance system. Governance system refers to the type of institutions that underpin and influence the actions of the leaders and other public office holders in a state, in the exercise of their authority in such areas as politics and the economy or in running of the affairs of a country (Eyinla, 2006). Along with institution, action and authority, a governance system also includes the behaviour and political culture of the governing elite. On this note, it is assumed that the type of governance system in place will determine and shape political behavior/institutional actions of the governing elite. Although political behavior/culture are integral parts of the type of political institutions in operation, it also includes such independent variables as; assumptions, tendencies and individual proclivity of the governing elite in operating the institutions (Daudu, 1985). On the specific connotation of governance, Olowu (2002), submit that:

...Governance emphasizes leadership and the manner in
which state political leaders manage, use or (misuse)
power whether to promote social and economic
development or to pursue agenda that undermine such
goals (Olowu, 2002:2)

The foregoing observation is very instructive. Whereas governance system prescribes the type of institution, authority, values, beliefs, political behavior and culture, the preoccupation of the governing elite (which is not necessarily conditioned by the prevalent governance system), will determine in concrete terms, the outcomes of a governance system. This preoccupation will in turn shape institutions, values, political culture and behavior in the long run. It is on this, note that we argue that, democracy as a governance system can be supplanted by another form of governance system if the preoccupation of the governing elite is anything but committed to promoting and institutionalizing the norms and values of democracy.

We have reflected earlier in the paper about the norms and values of democracy, but suffice to say that, democracy offers a complex system involving multiple feature (electoral institutions, parties, constitutional protection) and producing multiple goods (individual liberty, effective legislation, secure property rights, popular sovereignty). A governance system that lacks the capacity to institutionalize these features and generate the concomitant outcomes can be anything else but democracy. It is in the light against of this understanding that the governance system of democracies in Africa should be evaluated.

In his progress report on democratization in Africa, Diamond (2008) observed that the governance system of post-colonial Africa is neo-patrimonial and prebendal (see Joseph, 1987), because they combined elements of formal bureaucratic state with informal reality of personalized, unaccountable power and pervasive patron-client ties where the state resources is considered by the governing elite as personal slush to maintain political dominance. Prolonged authoritarian regimes have helped to nurture and preserve neo-patrimonial/prebendal governance system in Africa. For example, Uganda President Museveni has used state resources to bribe his continued stay in power. For Zimbabwe President Mugabe, his treatment of the country as his personal estate saw him in power for about four decades until his ouster via coup in 2017. However, in Nigeria where the third wave has tarried for two decades, the phenomenon of prebendalism has remained a predominant feature of her governance system. Whereas prebendalism in post-colonial Africa was enabled and sustained by authoritarian rule, the same phenomenon has taken the form of elite collusion (nurtured and sustained by liberal political conditions).

Elite collusion as a form of governance system got its inspiration from extant theories of social science such as the Elite Theory and the Theory of Public Choice. Therefore, to conceptualize elite collusion as a form of governance system, it might be helpful to undertake a sparing review of these social theories and then reflect on the sense in which they conspire to inspire elite collusion as governance. In the classical conception of elitism, Pareto (1935) and Mosca (1939) are in consensus that:

In all societies...Two classes of people appear - a class that rules and a class that is ruled. The first class, always the less numerous, performs all political functions, monopolize power and enjoys the advantages that power brings (Mosca, cited in Parry, 1979:39)

In their classic work The Calculus of Consent: Logical Foundation of Constitutional Democracies, James Buchanan and Gordon Tullock (1962), advanced the study of public choice and argue that: 
There is no public interest in the sense of being an interest of the whole public. There are only particular interests...The behavioural premise that call for legislator to follow a selfless pursuit of the 'public interest' or the 'general welfare' as something independent of and apart from private economic interest is severely threatened (Buchanan and Tullock, 1962:283)

In the elitist paradigm, contrary to the belief that liberal democracy has established mechanism for ensuring equity in the distribution of power, opportunities and influence, there have always been a few group of people who constitute the leadership strata in societies. These leadership strata are organized, cohesive and well protected, permitting only a minimal cooption of non-elite (in order to maintain stability and avoid revolution). In similar vein, the public choice paradigm sees bureaucrats and legislators as self-interested utility maximizers, motivated by the perquisite of office... (Niskanen, 1993). Thus, representative government is often flawed in that in making public choice from among alternatives for others as well as himself, the legislator is predictably opportunistic and self-interested.

The theses of elitism and public choice converge at the point where both theories admit the primacy of the governing elite in the society. The conceptual framework of elite collusion has only taken the argument further that in the final analysis, the governing elite are in constant collusion to promote and protect their narrow interest over and above the common good through a variety of mechanisms of institutional capture. We shall return to this later.

\section{Elite Collusion and the System of Public Administration}

The system of public administration captures the array of institutions, processes and structured pattern of behavior that are deployed to give effect to public policy. The institutional locus of public administration is the public service with a variety of formalized organizational structures for the conduct of government business. The public service (also referred to as the bureaucracy) is expected to provide the institutional support for democratic good governance. Thus, as an integral part of the governing elite, bureaucrats play a significant role in nurturing and sustaining elite collusion as a form of governance system. As permanent officials of government, the impact of the bureaucracy determines to a large extent the concrete outcomes of governance. However, the political superstructure of governance expresses the will of the state (and once they are given official sacrament), the system of public administration steps in to translate this will into concrete governance outcomes.

Although constitutional democracy has assigned separate roles to the political leadership and the bureaucracy, the tremendous influence of the latter in public policy making and implementation has severally compromised the raison d'etre of politics- administration dichotomy - a situation that has created opportunistic overlap in the policy process. This overlap has helped to nurture a policy environment that give vent to elite collusion. We shall return to this later. In the classical conception of politics- administration dichotomy, it is assumed that administration is divorced from the field of politics and based on a single organizational prototype universally applicable to all political regimes (Chandler and Plano, 1988). However, the intellectual debates on politics-administration dichotomy have produced stringent voices that are opposed to a water-tight separation (Pfeiffer; 1948; Appleby, 1949; Waldo, 1992; and Adamolekun, 1983). Waldo declared that politics-administration dichotomy is a misleading distinction which has become a fetish, a stereotype in the minds of theorists and practitioners alike. In his work A Theory of Public Administration Means in Our Time a Theory of Politics Also, Waldo asserts:

If one searches for a term to designate human collectivity in which politics and administration are well integrated, two of the terms considered certainly would be totalitarian and utopian. Patently, we are not currently at risk for totalitarianism or within sight of utopia. But if and as we seek to move towards the latter, we must be aware of the former (Waldo, 1992:82)

While admitting that a watertight separation is not practicable, Adamolekun (1983) observes that politicians dominate issues of high content of political judgment and a low content of technical expertise, whereas administrators dominate issues of high content of technical expertise and low content of political judgment. In the final analysis, Pfiffner (1948:7) summed up the debates that "...there is no denial that in a considerable number of instance, question of politics will be closely intermingled with administrative action". Beyond these 
neo-classical intellectual arguments, there are compelling strands of evidence to suggest that the bureaucracy has made considerable foray into the policy making arena. The intrusion of the bureaucrats into the jurisdiction of the politicians is often justified on account of the expert knowledge of the former, which the latter must leverage on in order to improve the quality of public policy. The desideratum of knowledge in public administration was acknowledged by Weber when he averred that precise calculation and systematic assessment of the various means of attaining a goal are involved in the construction of the rules which form the basis of bureaucracy (cited in Haralambo, 2001).

It is also assumed that as permanent officials of government, the bureaucrats provide the required institutional memory to ensure continuity in policy administration and governance. However, in the context of elite collusion, these bureaucratic virtues are exploited to the disadvantage of the larger public interest. The very knowledge of the file and technical expertise are partly responsible for undesirable governance outcomes such as; policy somersault/discontinuity, unpredictable policy trajectory and financial impropriety/corruption.

Policy somersault finds expression in the discontinuity and constant tinkering that have become regular features of the policy environment of developing economies. Change in political leadership often account for this policy discontinuity and abrupt change in policy direction. It is instructive to note also that; the subjective preference of top echelons of the bureaucracy also weighs heavily against policy continuity. Closely related to policy somersault is the issue of unpredictability of policy trajectory. Where a public policy is allowed to endure, the pre-eminence of the bureaucracy in policy implementation is sometimes manipulated to tinker with policy direction. A crucial stage of policy gestation is monitoring and evaluation. The bureaucracy (often driven by enlightened self-interest) may, in collusion with the politicians, pay lip service to this crucial stage. While the former does this damage to public policy by disconnecting from the feedback loop of the policy circle, the latter completes the damage by relaxing their oversight role.

Finally, financial impropriety has to do with authorization and control of public expenditure. Whereas the authorization of public expenditure is the constitutional prerogative of the politicians, the bureaucracy plays a decisive role in 'who gets what, when and how'. From such vantage position, funding of public projects and programmes is at the whim and caprice of bureaucrats. Given this overwhelming advantage, bureaucratic complicity in the massive and pervasive theft of public fund is unarguable.

\section{Discussion}

As the largest black nation on earth and the most populous in Africa, Nigeria approximates the despair as well as the hope of the entire continent. This arguably explains the pre-eminence of Nigeria in the general discourse of democratization and development in Africa. Hardly do scholarly reports on Africa's development trajectory pass the test of validity without identifying Nigeria as a classic example. Several explanations for this intellectual fixation in the development literature abound, the most persuasive being that, apart from her share size (in population and land mass), Nigeria is identified as the trigger of social transformation in Africa (on account of its location at the trigger of a short gun) which the map of Africa symbolize (Ozohu-Suleiman, 2016). On this note, we shall discuss the concrete manifestations of elite collusion as a form of governance system in Nigeria.

Nigeria has recorded almost two decades of unbroken democratization process. Thus, the liberal political conditions and the concomitant institutional infrastructure, processes and leadership tendencies have combined to generate governance outcomes that are more in deficit of the requirements of democratic good governance. Beyond the façade of the ability of people to live freely and autonomously as human beings (which democratic citizenship has engendered), the development that leads to improvement in quality of life indices for all, exist only in measures. The unenviable statistical figures on income inequality, rate of unemployment, prevalence of poverty, incidence of corruption and parlous human development indices are palpable indication that democracy is not connecting to development in Nigeria.

According to the National Bureau of Statistics (NBS), the level of inequality worsened from 0.356 in 2004 to 0.41 in 2013, and improved marginally to 0.391 in 2016. The downward trajectory recorded between 2004 and 2013 corresponds to 9 out of 14 years of the democratization process. Accordingly, $2 \%$ of an estimated population of 163 million Nigerians were responsible for $48.28 \%$ of national income in 2013 - a figure that declined marginally to $46.63 \%$ in 2016 (https://www.vanguardngr.com). In the 2017 (first quarter to third quarter) report of (NBS), the number of people within the labour force who are unemployed or underemployed in Q2 2017 and Q3 2017 increased from 13.6 million to 17.7 million and 15.9 million to 18.0 million respectively. The combined unemployment and underemployment rates for the entire youth labour force (age $15-35$ ) was 52.65\% or 22.64 million, compared to $45.65 \%$ in Q3 2016 and 41.7\% in Q4 2016 (https://www.nigerianstat.gov.ng).

The 2010 poverty profile in Nigeria (which was released in 2012 and remains the most current data on poverty), 
revealed that out of an estimated population of 163 million, a staggering 112.47 million Nigerians are poor, representing $69.0 \%$ of the population. Table 4 below captures the poverty incidence in Nigeria between 1980 and 2010 .

Table 4. Poverty incidence in Nigeria $(1980-2010)$

\begin{tabular}{llll}
\hline Year & Poverty Incidence (\%) & Estimated Population (Million) & Population in Poverty (Million) \\
\hline 1980 & 27.2 & 65 & 17.1 \\
1985 & 46.3 & 75 & 34.7 \\
1992 & 42.7 & 91.5 & 39.2 \\
1996 & 65.6 & 102.3 & 67.1 \\
2004 & 54.4 & 126.3 & 68.7 \\
2010 & 69.0 & 163 & 112.47 \\
\hline
\end{tabular}

Source: National Bureau of Statistics, 2012

The figures in table 4 above indicate a consistent rise in the number of Nigerians that are trapped in the circle of poverty relative to the increase in the estimated population. In 2004, the figure dropped marginally from $65.6 \%$ to $54.4 \%$ and picked up significantly to $69.0 \%$, in 2010 (indicating that more Nigerians became poor 11 years into the democratization process).

The United Nations Development Programme (UNDP) in its 2016 Human Development Report, ranked Nigeria $152^{\text {nd }}$ out of 188 countries surveyed. This ranking translates to 0.504 Human Development Index (HDI) which placed Nigeria among the lowest not only in the World but also in the continent of Africa. The report acknowledged that over the past 25 years, human development progress has been impressive, but the gains of the progress have not achieved universal spread. Thus, these imbalances have made it difficult if not impossible for people to reach their full potentials in life (http://hdr.undp.org/en/data). Obviously, the over 112 million Nigerians trapped in poverty are in the category of people who are lacking in multiple dimensions of human development. For a country that produces one of the World's largest volume of crude oil coupled with a variety of solid mineral deposits, these contradictions about the human condition in her territory, calls to question the integrity of government institutions and their handlers in respect of the application of the nation's commonwealth to improve the living standards of the people (see Ozohu-Suleiman, 2015). A notorious pre-deposing factor to the negative development indicators is corruption. In a report by Transparency International (2017), Nigerian ranked $148^{\text {th }}$ position out of the 180 countries evaluated in the Corruption Perception Index (CPI). This ranking translates to 28 score out of 100 - a figure lower than the average in Sub-Saharan Africa. In the 2016 ranking, Nigeria scored 28. In 2015 the score was 26. In 2014 the country scored 27 and 25 in 2013 (http://www.saharanreporter.com/2018/02/21/transparencyrank-nigeria). The 2017 score of 28 came against the backdrop of two years into a new regime that has promised zero tolerance for official graft.

Whereas corruption as predisposing factor to the development problematic in emergent democracies has received considerable attention in the literature, intellectual preoccupation is scanty on the nature, character and tendencies of the governing elite (that underlie the democratization process), and which have helped to nurture and sustain corruption and other forms of official malfeasance. The phenomena of policy reversal, unpredictable policy trajectory and legislative-executive collusion on public expenditure management are recurring decimal in Nigeria.

Many examples of policy reversals abound, but a few will suffice here. Some cases of policy discontinuity occurred in 2007 and 2008 one in the privatization policy and two in the education sector. In the privatization policy, some transactions namely sale of Kaduna and Port Harcourt refineries, sale of SAT3, takeover of NICON Insurance, sale of NITEL and some concession agreements were cancelled (Adamolekun cited in Ozohu-Suleiman, 2014). These reversals occurred in spite of the impressive achievements recorded in the liberalization of the telecommunication sector. However, it is interesting to note that the privatization of the nation's refineries is now hotly debated in the public domain, with the organized labour calling for the sustenance of the policy reversal, ostensibly on the ground that the policy was designed to deliver the nation's major source of wealth to the ruling class, who in the first place were responsible for its mismanagement (see the Guardian Newspaper, Dec., 18, 2013:4). In the education sector, the policies on Public-Private Partnership 
(PPP)for the management of 102 Federal Government Colleges and the merger of Polytechnics and Colleges of Education with Universities were reversed. In the grip of these policy somersaults, public interest is severely compromised.

On lack of predictability in policy trajectory, public policies targeted at infrastructure development and those on installing transparency/accountability are often the casualty of the enlightened self-interest of the governing elite. For the better part of the democratization process in Nigeria, government has created unparalleled record of abandoned projects. It was reported that the number of government projects that were abandoned stood at 19,000 (https://www.dailytrust.com.ng). A preponderance of these projects constitutes part of state intervention to address the huge deficit in the critical infrastructure needs of the country. Moreover, the comprehensive reform of the public service that started in 2001, and which among others aimed to establish service compact (SERVICOM) in order to address the question of how government can better connect with citizens to improve service delivery (Ozohu-Suleiman, 2010), has suffered lack of policy direction due largely to ineffective enforcement mechanism to drive improved service delivery. Thus, the SERVICOM campaign that generated a lot of excitement with the prospect of igniting a silent revolution in public service delivery has lost steam.

Also, the policy initiative that seeks to institutionalize transparency and accountability in the governance of extractive industries has been a victim of lack of policy direction. Part of the strategies for the implementation of this policy is the establishment of Nigeria Extractive Industries Transparency Initiative (NEITI). Since its establishment, NEITI has made considerable disclosures on the governance of extractive industries through its several reports. Regrettably, the government has done nothing to implement the far reaching recommendations in these reports. The National Assembly has also been found wanting in its oversight of the extractive industries (Ozohu-Suleiman, 2015).

On control of public fund, fault lines are deliberately created to provide opportunity for infractions. The power over authorization of public expenditure has been subject to abuse by the National Assembly through unnecessary delays in the passage of the Appropriation Bill. The executive has also been culpable for extra budgetary expenditure and gross abuse of due process of law. Thus, the respective roles of the politicians and bureaucrats on public expenditure management relate more to the abiding concern to furnish their personal interest rather than using the budget as instrument to grow the economy. On account of these fault lines, national budgets (over the years) are not usually ready until at least three months into the new fiscal year. Even as budget estimates await official sacrament, the National Assembly in collusion with the Ministries, Departments and Agencies (MDAs) of government, make insertions into the budget estimates.

Four of such insertions deserve mention here, they are; budgetary allocation for the highly contested constituency projects, arbitrary increases in the capital vote, the increase in the budget of the National Assembly, and the increase in votes to certain MDAs, whose chief executives have lobbied for such increases (Ozohu-Suleiman, 2013). Thus, the heavily publicized budget padding of the 2017 fiscal year is only reminiscent of what has become a notorious practice of indiscriminate alteration of budget figures. When the budget become operational, poor implementation is blamed on the executive owing to massive corruption in funds disbursement for projects and programmes implementation. However, the National Assembly also shares in this blame on account of its ineffective and ineffectual oversight of MDAs - a situation that the bureaucracy has often exploited to its advantage.

\section{Conclusion}

There is increasing optimism that the democratization process is significant to Africa's quest for good governance and development. However, this optimism is anchored on sustainable democratic reforms (taking into account the possibility of reverse wave from democracy to authoritarianism). Perhaps, one of the exceptionalities of Nigeria's political development experience is the reverse wave which occurred in 1983 after a stint of about five years of democratization. Commonly referred to as the 'Second Reverse Wave', Nigeria along with (Indonesia, Turkey, Pakistan, Greek and many Latin America countries) suffered a relapse to authoritarian rule - a development that equally set back the development process for several years. Two among the factors that account for the transition away from democracy in these countries are instructive. They are; the weakness of democratic values among the governing elite, and severe economic setbacks (which intensified social conflict predisposed the political system to authoritarian rule.

In Nigeria, the democratization process that commenced in 1999 has endured for about two decades now. Two decades of unbroken democratization process is significant to Nigeria's political and constitutional development in so far as it provides opportunity to address challenges that are associated with building democratic institutions and processes to sustain democratic rule, and promote democratic good governance. In interrogating the 
democratization process, the objective reality is that, the liberal political conditions engendered by democracy have been exploited by the governing elite to project their interest to the detriment of the common good.

This paper has largely fulfilled its mandate of substantiating this contradiction. Through a painstaking analysis of the complex interrelationship between the political governing elite group and the bureaucratic elite group, the paper has established how the hegemonic interest of the governing elite defines and shapes public policy and its concomitant outcomes. Democracy as a governance system is given, but the nature, character and tendencies of the governing elite can either sustain democracy and promote its cherished values and norms or supplant it with a variant of governance system that we refer to (in the case of Nigeria) as elite collusion. The paper concludes that the democratization process requires the intervention of ideologically constructed party politics to reconstruct the prevalent governance system.

\section{Recommendations}

In the light of arguments raised, observations made and issues discussion, the following recommendations become imperative:

1) There is need to realign the democratization process to embrace the variant of social democracy. Since development is about people, their livelihood and the choice they make that affect them, democracy remains the only governance system that can foster the necessary political conditions for people- driven and people-centered development. Therefore, given the widespread development deficit in the country and the urgency with which this deficit should be confronted, a social democracy that places emphasis on concrete political, social and economic rights as opposed to liberal democracy that projects the interest of the governing elite is urgently required.

2) Closely related to the foregoing is the call for ideologically constructed party politics to revitalize the democratization process. Party politics with strong ideological leaning that is cast in pro-masses agenda has been painfully absent in the Nigerian political system. Thus, to give impetus to a people-centered and people-driven development paradigm, there is need for political parties to commit to ideology that clearly define their approach to democratic good governance and inclusive development

3) To complement the role of ideologically constructed party politics, the democratization process should be inclusive of civil society, the organized labour, youth movement, women's group, professional bodies and the media. The interface between government and these critical mass of the population will create the platform to confront elite collusion as manifest or potential obstacle to good governance

4) Government should commit to building strong governance institutions that are rule bound, as opposed to the leadership myth that currently obtains. Strong and enduring institutions are required to truncate the phenomenon of policy reversal and policy somersault. Strong and rule bound institution is one that has tenacity over due process, adhere to organizational hierarchy and committed to formalized procedures (re-bureaucratization of a sort).

5) Finally, the system-wide reform of the public service that started in 2001 should be reappraised and refocused. There is convincing evidence that some of the gains of the reform have been lost due to inconsistency in its implementation. Findings reveal that the institutional framework for the implementation of service compact is unduly centralized, lacks enforcement mechanism and therefore ineffective. The Ministerial SERVICOM Units which is an attempt to decentralize and monitor implementation, often come under the undue influence of MDAs. Government should revisit the implementation strategy of SERVICOM with a view to developing enforcement mechanism that can yield positive results. To this end, the new Department of Reform Monitoring and Service Improvement is key to the idea of compliance enforcement.

\section{References}

Adamolekun, L. (2011). "A Transformation Agenda for Accelerating National Development”, being a lecture delivered on the occasion of the 2011 Presidential Inauguration Ceremonies, Thursday, May, 26.

Adejumobi, S. (2004). Democracy, Good Governance and Constitutionalism. In S. Odion- Akhaine (Ed.), Governance: Nigeria and the World. A Publication of the Centre for Constitutionalism and Demilitarization (CENCOD). Lagos: Panaf Press Ltd.

Ake, C. (2000). The Feasibility of Democracy in Africa. Dakar: CODESRIA.

Ake, C. (2001). Democracy and Development in Africa. Ibadan: Spectrum Books Ltd.

Anifowoshe, R., \& Enemuo, F. (2008). Elements of Politics. Lagos: Sam Iruansi Publications. 
Appleby, P. H. (1949). Policy Administration. Alabama: University of Alabama Press.

Bratton, M., \& Van de Walle, N. (1992). Popular Protest and Political Reform in Africa. Comparative Politics, 24. https://doi.org/10.2307/422153

Brownlee, J. (2009). Portents of pluralism: how Hybrid Regimes affect Democratic Transition. America Journal of Political Science, 53(3). https://doi.org/10.1111/j.1540-5907.2009.00384.x

Buchanan, J., \& Tullock, G. (1962). The Calculus of consent: Logical Foundation of Constitutional Democracy. Ann Anbor: University of Michigan Press. https://doi.org/10.3998/mpub.7687

Case, W. (2004). Comparative politics, Volume 37, No. 1, p. 83 - 104. https://doi.org/10.2307/4150125

Daudu, P. C. A. (1985). The New Political Infrastructure: Prospects for the Future. In J. F. A. Ajayi, \& B. Ikara (Eds.), Evolution of political culture in Nigeria. Zaria: University Press.

Diamond, L. (2008). The State of Democracy in Africa. In Democratization in Africa: What Progress towards Institutionalization? Conference Report of the National Intelligence Council (NIC), United States.

Diamond, L. (2014). Anatomy of Feckless State, Premium Times Nigeria. Retrieved from http://www.premiumtimes.nig.com

Dun, J. (1986). The Politics of Representation and Good Governance in Post-Colonial Africa. In P. Chabal (Ed.), Political Domination in Africa. Cambridge: Cambridge University Press. https://doi.org/10.1017/CBO9780511558795.009

Eyinla, B. (2006). Democratization and Governance in Africa. In A. A. Mohamoud (Ed.), Shaping a New Africa. Amsterdam: KIT Publishers.

Haralambo, M. (2001). Sociology: Themes and perspectives. New York: Oxford University Press.

Huntington, S. P. (1991). Democracy's Third Wave. Journal of Democracy, 2(2). https://doi.org/10.1353/jod.1991.0016

Ibori, M., \& Anakwe, A. (2017). Democracy and the Crises of Succession in Africa: Tenure elongation in Perspective. Journal of Science, Engineering and Technology, 4(2).

Ibori, S. M. (2014). The Collapse of Probity and Good Governance in Nigeria:The Bureaucracy Discharged but not Acquitted. Global Journal of Political Science and Administration, 2(4).

Johnson, J. (1991). Aid and Governance in Africa. The Round Table, 320. https://doi.org/10.1080/00358539108454060

Joseph, R. A. (1987). Democracy and Prebendal Politics in Nigeria: The Rise and Fall of The Second Republic. Cambridge: Cambridfe University press.

Leftwich. (2000). States of Development: On the Primacy of Politics in Development. Cambridge: Polity Press.

Lewis, P. (2008). Growth without Prosperity: Democracy, Poverty and Inequality in Africa. In Democratization, in Africa: What Progress Towards Institutionalization? Conference Report of the National Intelligence Council (NIC), United States.

Lynch, G., \& Crawford, G. (2011). Democratization in Africa 1990 - 2010: An Assessment. Retrieved April 11, 2018, from http://www.tandfoline.com/loi/fdem20

Mosca, G. (1939), The Ruling Class (Translated by Hannah D. Khan). New York: McGraw Hill Book Company.

National Bureau of Statistics. (2012). Poverty Incidence in Nigeria (1980-2010).

National Bureau of Statistics. (2016). Level of Inequality among Nigerians. Retrieved May 1, 2018, from https://www.vanguardngr.com

National Bureau of Statistics. (2017). Labour Force Statistics Vol. 1: Employment and under Employment Report. Retrieved May 1, 2018, from http://www.nigerianstat.gov.ng

Niskanen, W. A. (1993). Bureaucracy: Servant or Master? Institute of Economic Affairs, London.

Nzongola-Ntalaja, G. (2006). Democratic Transition in Africa. Journal of Constitutional Development, 6(1).

Olowu, D. (2002). Public Service Delivery. In L. Adamolekun (Ed.), Public Administration in Africa: Main Issues and Selected Country Studies. Ibadan: Spectrum Books Ltd.

Ozohu-Suleiman, A. (2010). Service Compact and Governance in Nigeria: A Perspective on the Reform of the Public Service. Paper Presented at an International Conference on 'Global Financial Crisis and Africa's 
Quest for Development', Organized by Faculty of Administration, Ahmadu Bello University, Zaria, Nigeria, Tuesday, $20^{\text {th }}$-Thursday $22^{\text {nd }}$, July, 2010.

Ozohu-Suleiman, A. (2013). Legislative-Executive Dichotomy in the Public Policy Process: A Perspective on the Nigeria's Fourth Republic. Global Journal of Political Science and Administration, 1(1).

Ozohu-Suleiman, A. (2014). Public Administration and the Collapse of probity and Good Governance in Nigeria: The Impact of Political Infrastructure. Global Journal of Political Science and Administration, 2(1).

Ozohu-Suleiman, A. (2015). The Report of a Public Perception Survey of the Nigeria Extractive Industries Transparency Initiative (NEITI), prepared for; the Civil Society Legislative Advocacy Centre (CISLAC), Abuja.

Ozohu-Suleiman, A. (2016). Democracy, Good Governance and Development in Nigeria. Journal of Public Administration and Policy Research, 8(7).

Pareto, V. (1935). The Mind of Society. London: Jonathan Cape.

Pfeiffer, J. (1948). The Federalists: A Study in Administrative History. New York: Macmillan.

Sesay, A. (2014). African Governance Systems in Pre and Post-Independence periods: Enduring Lesson and Opportunity for Youth in Africa, A Discussion paper prepared for the Mandela institute for Development Studies (MINDS).

The Guardian Newspaper, December, 18, 2013, pg. 4.

Ulla-Jan, A. (2003). The End of Democracy. Canada: Pragmatic Publishing and Distributors.

UNDP. (2006). Governance for the Future: Democracy and Development in the Least Developed Countries. United Nations Office of the Representative for Least Developed Countries.

United Nations Human Development Programme. (2016). Human Development Report. Retrieved from http://hdr.undp.org/en/data

Waldo, D. (1992). A Theory of Public Administration Means in Our Times a Theory of Politics Also. In N. B. Lynn, \& A. Wildavsky (Eds.), Public Administration: State of the Discipline. New Jersey: Chatham House Publishers.

Yaqub, N. (1994). Future of Democracy in Africa: Beyond the Transition. In O. Omoruyi, D. B. Schlosser, A. Sambo, \& A. Okwuosa (Eds.), Democratization in Africa: African Perspectives (Vol. 2). Benin City; Hima \& Hima Ltd.

\section{Copyrights}

Copyright for this article is retained by the authors, with first publication rights granted to the journal.

This is an open-access article distributed under the terms and conditions of the Creative Commons Attribution license (http://creativecommons.org/licenses/by/4.0/). 